\title{
薬物依存における脳内報償系細胞の機能変化に 関する電気生理学的検討
}

\author{
天野 託 ${ }^{1)}$ ，関 貴弘 ${ }^{1)}$ ，松林 弘明 ${ }^{1)}$ ，笹 征史 ${ }^{2)}$, 酒井 規雄 ${ }^{1)}$
}

要約：メタアンフェタミン（MAP）を 5 日間反復投 与し, 側坐核ニューロンと腹側被蓋野ドパミンニュー ロンのドパミンレセプターに対する感受性を検討した。 MAP 最終投与後 5 日後では, 生体位の実験において, マイクロイオントホレーシスにより投与したドパミン およびMAP 対し，側坐核のニューロンは過感受性を 示した。また，スライスパッチクランプ法を用いた実 験でも，生体位と同様にD2 レセプターに対する感受 性の充進が起こっていた。腹側被蓋野ドパミンニュー ロンの D1 および D2 両レセプターもドパミンに対す る感受性光進が起こっていることが，スライスパッチ クランプ法を用いた検討でも明らかになった。さらに, 最終投与後 5 日後において, 実験終了後のピペットか ら回収した mRNAをRT-PCRにより増幅した結果,

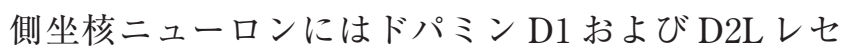
プターの mRNA が存在していたが，両受容体の mRNA の発現パターンは生食投与群抒よび MAP 投与 群で, 変化は認められなかった。 以上の事から, MAP 反復投与により，腹側被蓋野ドパミンおよび側 坐核ニューロンに扔いてドパミンレセプターの過感受 性が起こると考えられる。しかし，ドパミンレセプタ 一サブタイプの分画に変化がなく，抒そらく細胞表面 で作用する D2 レセプター密度の増加か, 細胞内伝達 系の変化により D2 レセプターの機能が立進している 可能性が考えられる. MAPによるD2レセプターの 感受性の変化にプロテインキナーゼ C (PKC) が関与 しているかを GFP 標識 PKC (PKC-GFP) のトラン スロケーションをコンフォーカルレーザー顕微鏡下に 観察し検討した。MAPの急性投与はSHSY-5Y 細胞
において PKC-GFP のトランスロケーションを引き起 こさなかった。

\section{はじめに}

覚せい郕であるメタアンフェタミン (MAP) やア ンフェタミンの精神依存の強さはコカインやモルヒネ より弱く，アルコールと同等かそれ以上であり，これ ら薬物により明暸な身体依存は形成されないとされて いる. 覚せい凨の長期使用により, 幻覚・妄想状態等 の精神病様症状を生じることが知られている。このよ うな精神病様症状は, 治療によって軽快するが, MAPの再使用，或いは心理社会的なストレスで再燃 する(1)。この現象は感作 (sensitization) あるいは逆 耐性現象と呼ばれ統合失調症の発症脆弱性の概念とし て注目されている. 同様に動物実験においても MAP を反復投与すると常同行動・自発運動量が増加し, 長 期断薬後においても以前には効果を示さなかった少量 の MAP の投与でこの常同行動・自発運動量の増加が 再現されることが知られている(2)。この現象も逆耐 性現象あるいは行動の感作と呼ばれ統合失調症発症モ デルとして使用されている(2-4)。これらの異常行動 はいずれも，ハロペリドールなどのドパミン D2 受容 体遮断薬によって抑制されることから D2 受容体を介 する反応と考えられている。覚せい剤連用による逆耐 性あるいは行動感作の発現は神経細胞とそのネットワ ークに打ける変容によるものと考えられる。本稿では 覚せい剂反復投与による神経細胞機能变容について 我々の研究成績を中心に述べてみたい。

キーワード：メタンフェタミン, ドパミンレセプター, 逆耐性, 依存, 電気生理学

1) 広島大学 大学院 医歯薬学総合研究科 創生医科学専攻 病態探究医科学講座 神経精神薬理学教室

( ○734-8551 広島市南区霞 1-2-3)

e-mail: t-amano@hiroshima-u.ac.jp

2) 渚病院（=573-1183 枚方市渚南町 24-31）

原稿受領日：2005 年 2 月 24 日, 会誌編集員会依頼原稿

Title: Electrophysiological analysis of brain reward system in drug addiction and dependency

Author: Taku Amano, Takahiro Seki, Hiroaki Matsubayashi, Masashi Sasa, Norio Sakai 


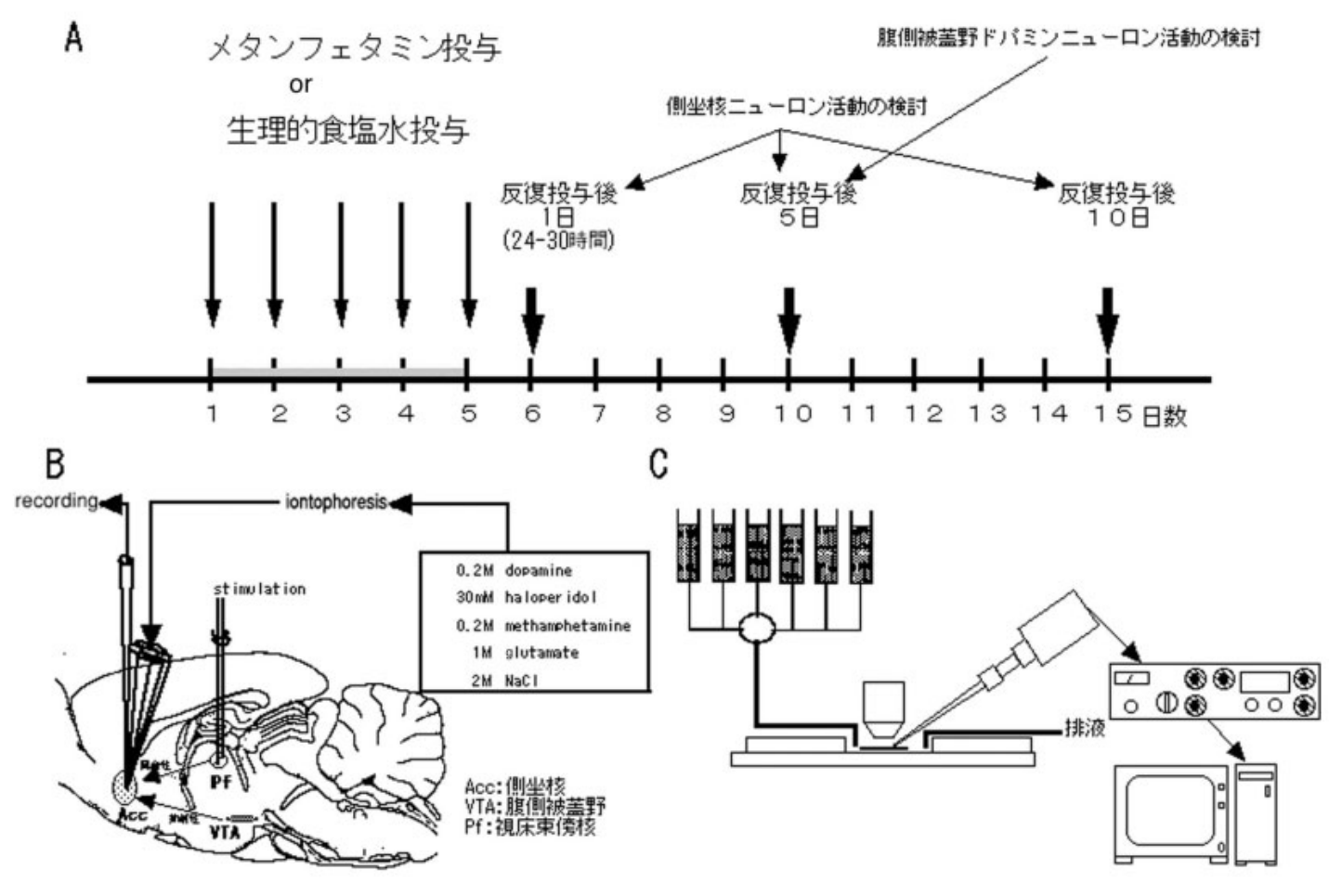

図 1 実験のスケジュール (A). In vivo（B）とスライスパッチ (C) 実験概略図

\section{1. ドパミン系細胞に対する覚せい剤の作用}

中枢神経系におけるドパミン神経系は，11腹側被蓋 野に存在するドパミン産生細胞から大脳皮質前頭野・ 辺縁系へ投射する，腹側被蓋野 - 大脳辺縁系，(2)黑質 緻密部に存在するドパミン細胞から線条体に投射する, 黒質 - 線条体系および(3)視床下部のドパミン細胞から 下垂体後葉に投射する，視床下部 - 下垂体系の 3 経路 から成る. その中で, 逆耐性現象における可逆性変化 は(1)の経路である腹側被蓋野の $\mathrm{A}_{10}$ ドパミンニューロ ンから側坐核への投射経路の過剰活動が重要な役割を 果していると考えられている。

視床から入力を受ける側坐核ニューロンはドパミン D2 受容体を介して腹側被蓋野からドパミン性抑制を 受けている(5-8)。また, 麻酔ラットを用いた研究に おいて側坐核ニューロン活動はマイクロイオントホレ ーシス法により記録ニューロン近傍に投与したメタン フェタミン (MAP) によって抑制され，この抑制は ドパミン D $1 / \mathrm{D} 2$ 受容体アンタゴニストのハロペリド ールによって拮抗された。このことから，MAPによ る側坐核ニューロンの抑制は, MAPがドパミン神経 末端からドパミンを遊離し，かつ再取り达みの抑制に よりシナプス領域にドパミンを増量させた結果である と考えられる $(9)$. そこで我々はメタアンフェタミン
の反復投与後において，側坐核ニューロン活動にどの ような変化が起こるかを明らかにするため，次のよう な実験を行った (6).

\section{2. in vivoにおける検討（6）}

成熟雄性ウイスターラットに，メタンフェタミン 5 $\mathrm{mg} / \mathrm{kg}$, i.p. (MAP 投与群) もしくは生理的食塩水（PS 投与群）を毎日 1 回，腹腔内へ 5 日間投与した（図 1A). 最終投与 24 〜 30 時間， 5 日および 10 日後に抱 水クロラール麻酔下に動物を脳定位固定台に固定し, 実験を行った。 7 極微小ガラス管に張り合わせたガラ ス管微小電極を用い, 側坐核のニューロン活動を細胞 外に記録した. 7 極微小ガラス管には $1 \mathrm{M}$ グルタミン 酸， $0.2 \mathrm{M}$ ドパミン， $0.2 \mathrm{M}$ メタアンフェタミン， 30 $\mathrm{mM}$ ハロペリドール, $2 \mathrm{MNaCl}$ などを充填し, これ らを記録ニューロン近傍にマイクロイオントホレーシ ス法により投与した（図 1B）。刺激電極を視床束傍核 (視床：Pf）に刺入し，この電極を介して刺激を与え ることによりスパイクを生ずる側坐核ニューロンにつ いて検討をおこなった。

\section{1）視床誘発スパイクに対する検討}

視床を刺激すると側坐核のニューロンに順行性のス パイクが得られる (図 2A). PS 群において, 視床誘 発スパイクは, マイクロイオントホレーシス法により 

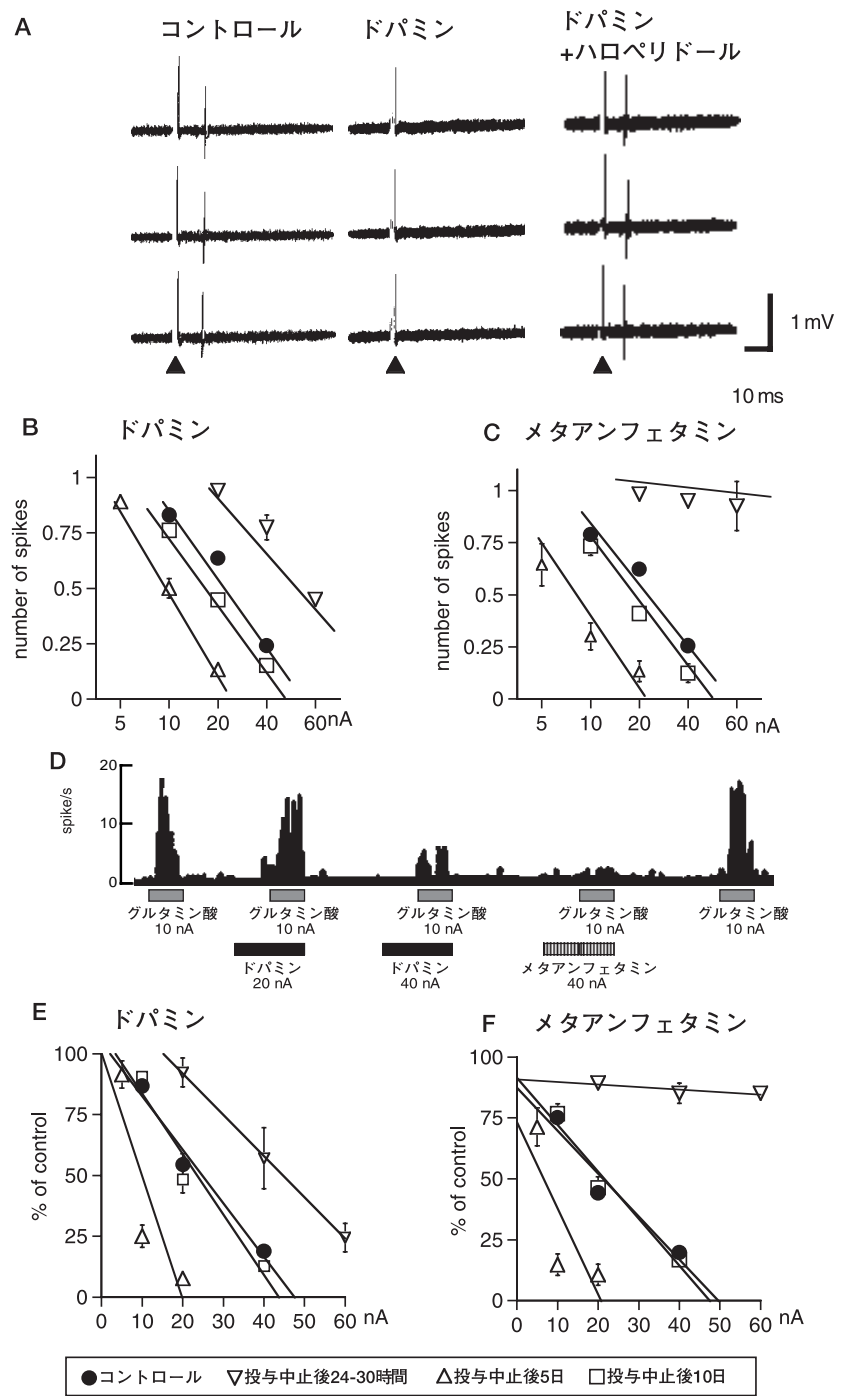

図2 ABC : 生理食塩水処置ラット (PS 群) において視床束 傍核刺激により側坐核ニューロンに発生するスパイクのドパミ ンによる抑制作用 $(A)$. 視床束傍核刺激誘発側坐核ニューロ ンスパイクに対するドパミン (B) およびメタアンフェタミン (C) の用量作用曲線.

、 : 視床束傍核刺激, 数值はマイクロイオントホレーシス法によ り投与した用量 (電流: $\mathrm{nA}$ ) を示す。縦軸 $(\mathrm{B}, \mathrm{C})$ は視床を 1.4 秒毎に 10 回刺激を与えた時に得られるスパイク数の 1 回刺激あた りの平均スパイク数を表す

DEF : 生理食塩水投与ラット (PS 投与群) におけるグルタミ ン酸誘発スパイクに対するドパミンおよびメタアンフェタミン による抑制作用 (D). グルタミン酸誘発スパイクに対するド パミン (E) およびメタアンフェタミン (F) の用量作用曲線. 数値はマイクロイオントホレーシス法により投与した用量（電流： $n A)$ を示す。縦軸（E，F）はグルタミン酸によって誘発される 1 秒間当りの最大スパイクを $100 \%$ とし，ドパミンまたはメタアンフ エタミン投与下のグルタミン酸誘発スパイク数の最大を\%で表す (文献 6 より改变)

投与したドパミンおよびメタンフェタミン（MAP） によって抑制された（図 $2 \mathrm{~A}$ )。視床に 1.4 秒に 1 回の 頻度で刺激を加え連続 10 回のスパイク発火数を測定し, 1 回の刺激あたりに発火する平均をスパイク数と定め た。このスパイク数を縦軸に，ドパミン，MAPの用 量（イオントホレーシス装置に流した電流）を横軸に
用量反応曲線を作成し，このスパイク数を $50 \%$ 抑制 する電流值である $\mathrm{EC}_{50}$ 值を求めて比較検討した。 ド パミン，MAPによる視床スパイクの抑制は用量依存 的であった（図 $2 \mathrm{~B} ， \mathrm{C}$ )。メタアンフェタミンを 5 日 間反復投与した後，最終投与 $24 \sim 30$ 時間後において は，ドパミンは用量依存性に視床誘発スパイクを抑制 したが，PS 投与群に比べ有意に高用量を要し， $\mathrm{EC}_{50}$ 值は高值であった。 また，最終投与 $24 \sim 30$ 時間後に おいてはメタアンフェタミンに対する感受性も低下し, $\mathrm{EC}_{50}$ 值は $100 \mathrm{nA}$ 以上であった。このことは断薬 24 〜 30 時間後においては側坐核ニューロンはドパミン とメタアンフェタミンに対して低感受性になることを 示している。一方，MAP最終投与 5 日後においては, 側坐核ニューロンはドパミンおよびメタアンフェタミ ンに対し感受性の克進を示した。スパイクの抑制を起 こすドパミンおよび $\mathrm{MAP} の \mathrm{EC}_{50}$ 值は， PS 投与群よ りも有意に低值であった（図 $2 \mathrm{~B}, \mathrm{C}$ )。しかし，MAP 最終投与 10 日後においては，側坐核のニューロンの ドパミンおよび MAP に対する反応性は PS 投与群と 同様のレベルに復した（図 $2 \mathrm{~B}, \mathrm{C})$ 。ドパミンと MAP による視床誘発スパイクの抑制はハロペリドールによ って，いずれも拮抗された。このことからメタアンフ エタミンによる抑制も遊離されたドパミンがドパミン 受容体に働いため惹起されたと考えられる。この場合 関与するドパミン受容体は D1/D2 およびD3 受容体 であると考えられる $(5,6,10)$.

\section{2）グルタミン酸誘発スパイクに対する検討}

側坐核ニューロンの自発発火はきわめて低い。この ニューロンにグルタミン酸をイオントホレーシス法に より投与すると発火の立進が認められる（図 2D）. PS 投与群において，側坐核ニューロンのグルタミン 酸誘発スパイクは，ドパミンおよびMAPにより用量 依存性に抑制された（図 $2 \mathrm{E} ， \mathrm{~F}$ )。グルタミン酸によ つて誘発される 1 秒間の最大スパイク数を $50 \%$ 抑制 する $\mathrm{EC}_{50}$ 值は，視床誘発スパイクに対するものとほ ぼ同程度であった。これらの抑制は，ハロペリドール $40 \mathrm{nA}$ により，いずれも拮抗された。

メタアンフェタミン最終投与 $24 \sim 30$ 時間後におい ては視床誘発スパイクの場合と同様，ドパミンおよび メタアンフェタミンの用量作用曲線は右方にシフトし, 側坐核ニューロンはドパミンとメタアンフェタミンに 低感受性を示した。ドパミンの $\mathrm{EC}_{50}$ 值は高值を示し， メタアンフェタミンの作用は認められなかった。一方, メタアンフェタミン最終投与 5 日後においては視床ス パイクの場合と同様，ドパミンおよびメタアンフェ夕 ミンに対する感受性は充進し，用量作用曲線は左方移 
動した（図 $2 \mathrm{E} ， \mathrm{~F})$. ドパミンおよびメタアンフェ夕 ミンの $\mathrm{EC}_{50}$ 值は, $\mathrm{PS}$ 投与群と比較して有意に低值 を示した。メタアンフェタミン最終投与 10 日後には ドパミンおよびメタアンフェタミンのグルタミン酸誘 発スパイク抑制効果はコントロール群と同様のレベル に復した（図 $2 \mathrm{E}, \mathrm{F})$.

\section{In vitroでの検討}

1）腹側被蓋野ドパミンニューロンにおける検討（11） 生体位に押いては，上記のように MAPを 5 日間反 復投与した場合，側坐核ニューロンはマイクロイオン トホレーシス法により投与したドパミンおよび MAP に対し，最終投与後 $24 \sim 30$ 時間後においては低感受 性を示し, 最終投与後 5 日後においては過感受性を示 し，10日後には生理的食塩水投与群の動物における と同程度の感受性を示した。そこで，同様の処置によ り，腹側被蓋野ドパミンニューロンのドパミンに対す る感受性に変化が起こるか否かについてスライス標本 を用い，パッチクランプ法により検討を行った(11).

雄性 Wistar ラット（生後 7 日齢より）に MAP（1 $\mathrm{mg} / \mathrm{kg} /$ 日, s.c.) を連続 5 日間投与し，コントロー ル群として同用量の生理的食塩水（PS）を同様に投 与した（図 1A，C).

最終投与より 5 日後に断頭し, 水冷下に腹側被蓋野 を含む厚さ $150 ２ 00 \mu \mathrm{m}$ のスライス標本を作成し， 通常の人工脳脊髄液（イオン組成 $(\mathrm{mM})$ は : $\mathrm{NaCl}$, 113; $\mathrm{KCl}, 3 ; \mathrm{NaHCO}_{3}, 25 ; \mathrm{NaH}_{2} \mathrm{PO}_{4}$, 1; glucose, 11; $\mathrm{CaCl}_{2}, 2 ; \mathrm{MgCl}_{2}, 1 ; \mathrm{pH}$ 7.4）にて灌流している小水 槽内に保持した。パッチ電極（イオン組成 $(\mathrm{mM})$ は： K-gulgonate, $130 ; \mathrm{KCl}, 10 ; \mathrm{NaCl}, 9 ; \mathrm{MgCl}_{2}, 1$; HEPES，10; EGTA，0.2; pH7.4）を用い，顕微鏡直視 下に腹側被蓋野ドパミンニューロンを同定し，室温下 にホールセル記録を行った。薬物は $1 \sim 3 \mathrm{ml} / \mathrm{min}$ 速 度で灌流している液中に投与した。

腹側被蓋野ドパミンニューロンの特徴は, 静止膜電 位はー 50 〜 $60 \mathrm{mV}$ であり, 深くて, 長い潜時（10 $\mathrm{mV}, 300 \mathrm{msec}$ 以上）をもつ afterhyperpolarization を 有し, 一般に $2-3 \mathrm{~Hz}$ 以下の低頻度の自発発火が認め られる。また，細胞に 1 秒間の過分極性の step pluses を加えると, 膜電位が過分極になるほど, 膜電位に time-dependent sag (time-dependent voltage sag or time dependent hyperpolarizing rectification） が観察 される事が特徵である(11-14)。これらの電気生理学 的特徴からドパミン細胞同定し実験に使用した。

電流固定下に電位変化を測定するとドパミンニュー ロンはドパミンおよび D 2 レセプターアゴニストであ
る talipexoleにより用量依存的に過分極を示した。そ の過分極は PS 投与群より MAP 投与群で有意に増大 していた（図 3A，B，D）。一方，MAP拈よび SKF38393（D1 アゴニスト）の単独投与は生理的食塩 水 (生食) 投与群も MAP 最終投与群に打いても膜電 位に影響を及ぼさなかった（図 3C，D）。しかし， SKF38393 は talipexole との同時投与により, talipexole 単独投与よりもさらに大きな過分極が認められ, この D1 アゴニストによる D2 アゴニスト作用の増大 効果は MAP 投与群の投与中止 5 日後にさらに増大し た（図 3D).

腹側被蓋野ドパミンニューロン活動はその樹状突起 から遊離されるドパミンにより $\mathrm{D} 2$ レセプター（オー トレセプター）を介して抑制される。この抑制はオー トレセプターを介してカリウムチャネルが活性化・開 口し，細胞外に $\mathrm{K}^{+}$が流出して過分極が起こることに よると考えられる．また，D1 レセプターの活性化の みではドパミンニューロンに変化はきたさないが, D2 レセプターの活性化と同時にD1レセプターが活 性化されると，D2 アゴニストの作用が増大する，つ まり，D1 アゴニストは単独では効果がないが，D2ア ゴニストによる過分極に対し相乗的に作用すると考え られる. D1アゴニストと D2アゴニストの同時投与 による過分極から D2 アゴニスト単独よる過分極を差 し引いたものが D1 アゴニストの作用と考えられ，そ の差（D1 アゴニストによる効果）が生食群よりも MAP 投与群の方がより大きくなったことから D1 レ セプターを介する反応も MAP 投与群で充進している と考えられる。

\section{2）側坐核ニューロンにおける検討}

上記のように，MAPの反復投与により，生体位の 実験下の側坐核ニューロンはドパミンおよびMAPに 対し，最終投与後 5 日後においては過感受性を示した。 そこで，同様の MAP の反復投与により，側坐核ニュ ーロンで過感受性が起こるか否かを検討する為に, IR-DIC（赤外線カメラ）を用いスライスパッチクラ ンプ法を行い, 側坐核ニューロンでの, 感受性の変化 を検討した. MAP ( $1 \mathrm{mg} / \mathrm{kg} /$ 日, i.p. : MAP 投与群) あるいは生理的食塩水（PS 投与群）を，生後 5 週目 の雄性 Wistar ラットに 5 日間反復投与し, 最終投与 より 5 日後に断頭し，氷冷下に側坐核を含む厚さ 500 $\mu \mathrm{m}$ のスライス標本を作成し実験に使用した。 人工脳 脊髄液（灌流液）およびパッチ電極液は上記組成のも のを使用した。

側坐核ニューロンはドパミンレセプターの存在を電 気生理学的に判別できないため, ドパミンに対して反 
A

PS投与群

ドパミン $100 \mu \mathrm{M}$
B

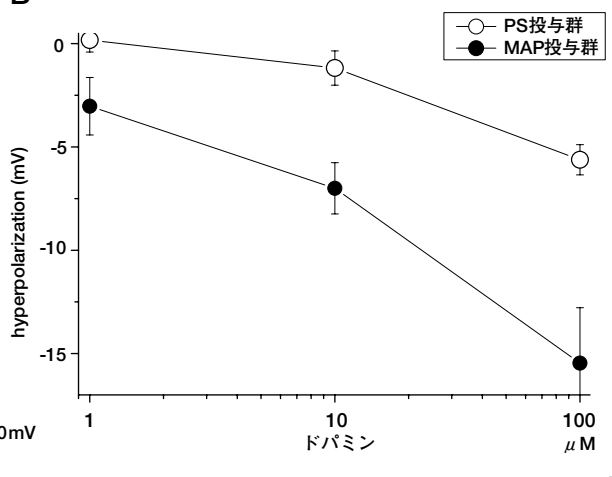

C
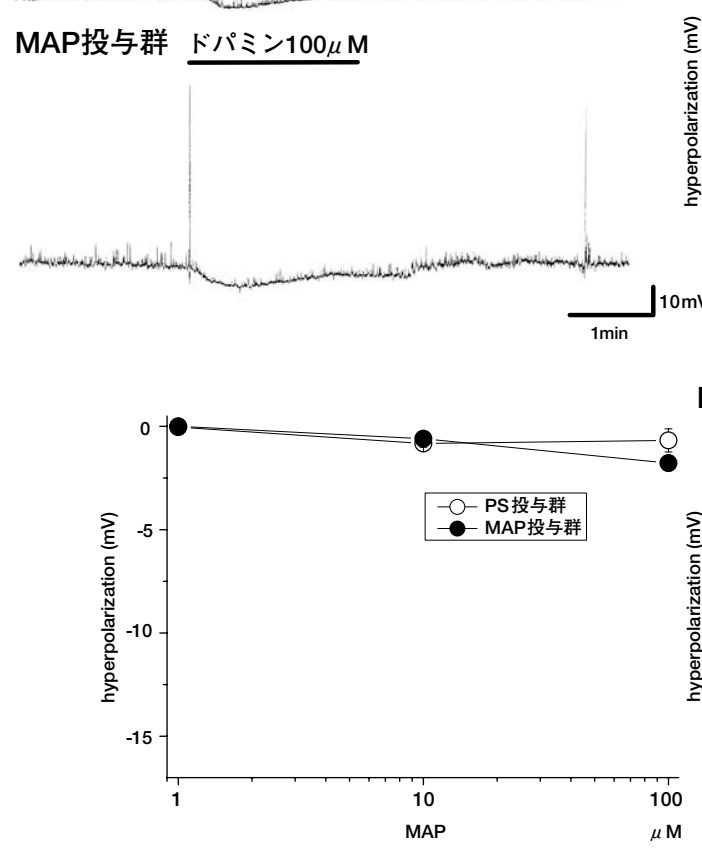

-O- talipexole (PS投与群) SKF38393 +talipexole (MAP投与群) SKF38393 +talipexole (PS投与群) SKF38393 (MAP投与群) SKF38393 (PS投与群) talipexole (MAP投与群)

図 3 生理食塩水投与 (PS 投与群) とメタアンフェタミン投与 (MAP 投与群) ラットにおける, 腹側被蓋野 (VTA) ドパミンニュー ロンに対するドパミンの抑制効果 (A). PS 投与群と MAP 投与群におけるドパミン (B), MAP (C), タリペキソール (D2アゴニス ト) (D) およびSKF38393 (D1 アゴニスト) (D) のVTA ドパミンニューロンの膜電位に対する用量作用曲線.

横軸は濃度。縦軸は過分極の度合いを示す。(文献 11 より改变)

応のあったものを使用した。側坐核ニューロンにおけ る, PS 投与群と MAP 投与群の, 静止膜電位, 大き さ (直径), 膜容量 (capacitance) および input resistance には有意の差は認められなかった. PS 投与群で は検討したすべてのニューロンでは自発発火は認めら れなかったが，MAP投与群では約 80\%のニューロン に自発発火が認められた。この自発発火は抢そらくグ ルタミン酸などの放出や GABA の抑制が関与してい ると考えられるが，詳細については今後の検討課題の 一つである.

今回はドパミン受容体の過分極の強度についてのみ 検討した. PS 投与群および MAP 投与群の両群につ いて電流固定下にドパミン $1 \sim 100 \mu \mathrm{M}$ および $\mathrm{MAP} 1 \sim 100 \mu \mathrm{M}$ を投与した場合, 両群のニューロ ンに用量依存性の過分極が認められた（図 4). 生食 投与群よりも MAP 投与群において有意に大きなドパ ミンおよび MAPによる過分極が認められた(図 4B,C). さらに，D2/D3 アゴニストのキンピロール（1～ 100 $\mu \mathrm{M})$ を投与した場合にも用量依存性の過分極が認め られ，キンピロールによる過分極も生食投与群よりも MAP 投与群において, 有意に大きくあらわれた（図
4D). また, 実験終了後の電極内に得た mRNA をRTPCRにより増幅した結果，側坐核には D1，D2L およ び D3 レセプターが認められたが，D4 および D5 レセ プターの mRNA は存在しなかった。さらに, 生食群 と MAP 投与群とに抏いてドパミンレセプターサブタ イプの分画には変化は認められなかった（デー夕提示 なし).

以上まとめると側坐核ニューロンの一般的電気生理 学的性状は反復 MAP 投与によって変化しなかったが, ドパミン，MAP および D2/D3 アゴニストのキンピロ ールに対する過分極反応は PS 投与群より MAP 投与 群に扔いて充進していた。このことから MAP 反復投 与による MAP に対する感受性の充進は側坐核ニュー ロンの D2レセプターに対して起こっていることが明 らかになった。一方, 実験終了後のニューロン内から 得た mRNAをRT-PCRにより増幅したところ，各ド パミンレセプターサブタイプ mRNA の発現パターン には変化が認められなかった。本法では mRNAの量 的変化の定量はできないが, 電気生理学的成績と考え 合わせると，MAP 反復投与後のドパミンと MAPに 対する感受性の充進は, 細胞表面で作用するドパミン 

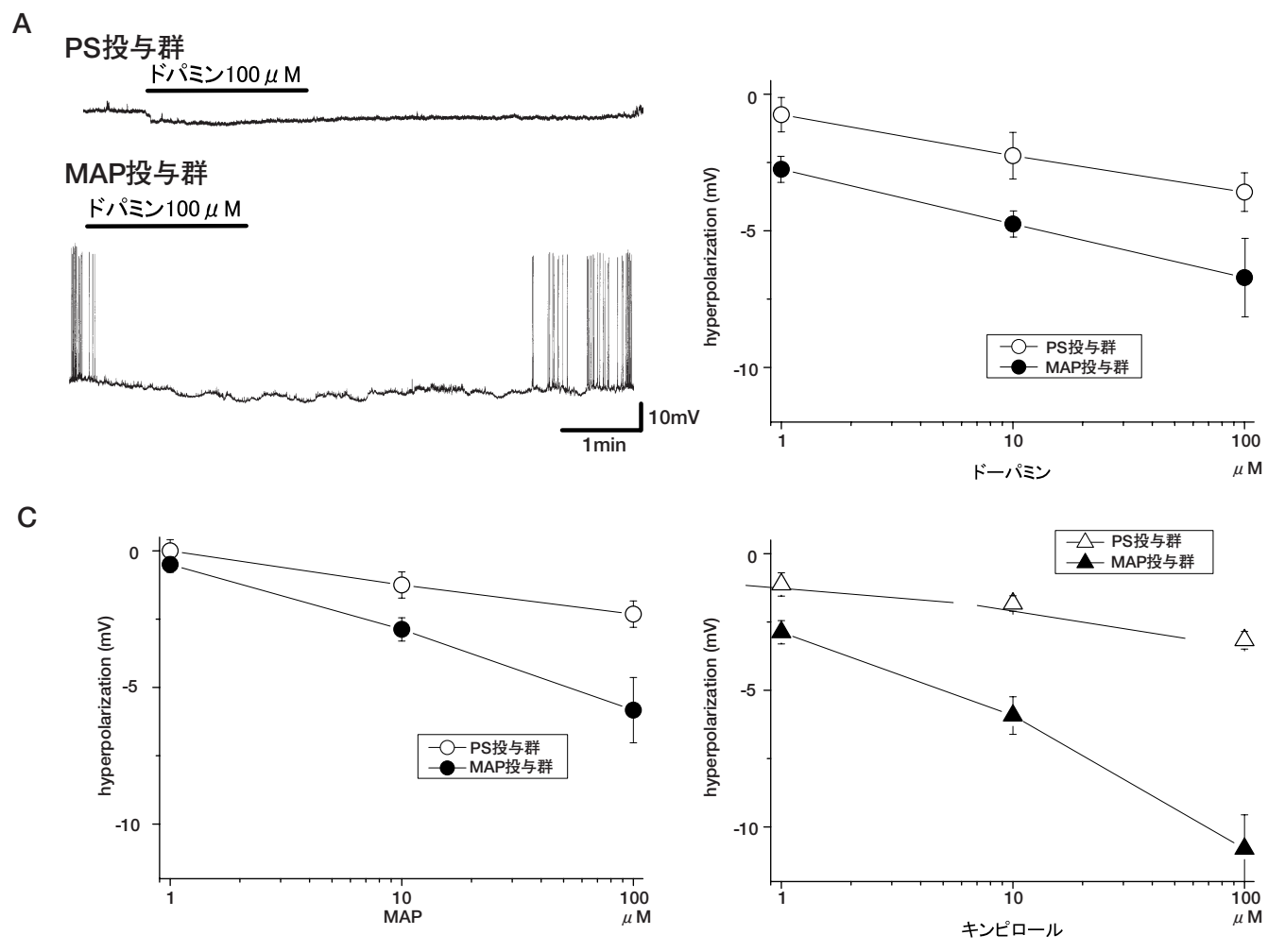

図 4 生理食塩水投与 (PS 投与群) とメタアンフェタミン投与 (MAP 投与群) ラットにおける, 側坐核 (Acc) ニューロンに対する ドパミンの抑制効果 (A). PS 投与群と MAP 投与群におけるドパミン (B), MAP (C) およびキンピロール (D2/D3 アゴニスト) (D) の ACc ニューロンの膜電位に対する用量作用曲線. 横軸は濃度. 縦軸は過分極の度合しを示す。

D2 レセプター密度が増加した可能性と, 細胞内伝達 系の変容により D2 受容体の機能が変化した可能性が 考えられる。

\section{4. メタンフェタミンによるD2受容体の感受 性変化にプロテインキナーゼC（PKC）は関 連するか?}

タンパク質リン酸化酵素は, 受容体の膜輸送やエン ドサイトーシスの調節あるいは受容体自身のリン酸化 により，その機能を修飾する。その中でもプロテイン キナーゼ C (PKC) は様々な機能性膜タンパク質の修 飾にあづかる事が知られている，PKC はセリン・ス レオニンリン酸化酵素で, 受容体刺激による脂質代謝 産物により活性化される. PKC は少なくとも 10 種類 のサブタイプが報告され, その構造の違いから $\mathrm{cPKC}$ (classical PKC), nPKC (novel PKC) と aPKC (atypical $\mathrm{PKC}$ )の 3 種類に大別されている.すなわち, cPKC の調節領域には DG やホルボールエステルが作用する 2 つの C1 ドメインとカルシウムが結合する C 2 ドメ インが存在する。一方, nPKC には C2 ドメインがなく, $\mathrm{aPKC}$ には $\mathrm{C} 2$ ドメインのほかに 1 つの $\mathrm{C} 1$ ドメイン が欠損している(15)。これらサブタイプは cPKC とは
活性化機構が異なっていると考えられる.PKCは活 性化される際に, 細胞質から細胞膜あるいは, 他の細 胞内器官に局在が変化する（トランスロケーションす る）事が明らかになっている(16)。MAPによるD2 レセプターの感受性の変化に PKC が関与しているか を明らかにする目的で, まず MAP 自身がPKCにト ランスロケーションを引き起こし PKC を活性化させ るか否かを検討した。

cPKC の代表として $\gamma \mathrm{PKC}, \mathrm{nPKC}$ の代表として $\delta$ $\mathrm{PKC}$ および $\mathrm{aPKC}$ の代表としてらPKC に蛍光タンパ ク質 Green Fluorescent Protein（GFP）を融合したも のを SHSY-5Y 細胞（ヒト神経芽細胞腫由来でドパミ ンを含有）に発現させ MAPによる PKC のトランス ロケーションをコンフォーカルレーザー顕微鏡で観察 した。まずコントロール実験として，この細胞にカル バコール $(1 \mathrm{mM})$ 刺激を与えると， $\gamma$-PKC-GFP は 細胞膜へトランスロケーションを起こし, 10 分以内 に細胞質に戻った（図 5A)。しかし, MAP (100 $\mu \mathrm{M})$ の急性投与は， $\gamma$-PKC-GFP の細胞膜へのトランスロ ケーションを引き起こさかなった（図 $5 \mathrm{~B}$ ). 同様に, MAP 急性投与は $\delta$-PKC-GFP も $\zeta$-PKC-GFP のトラ ンスロケーションも惹起しなかった。以上の結果より, 

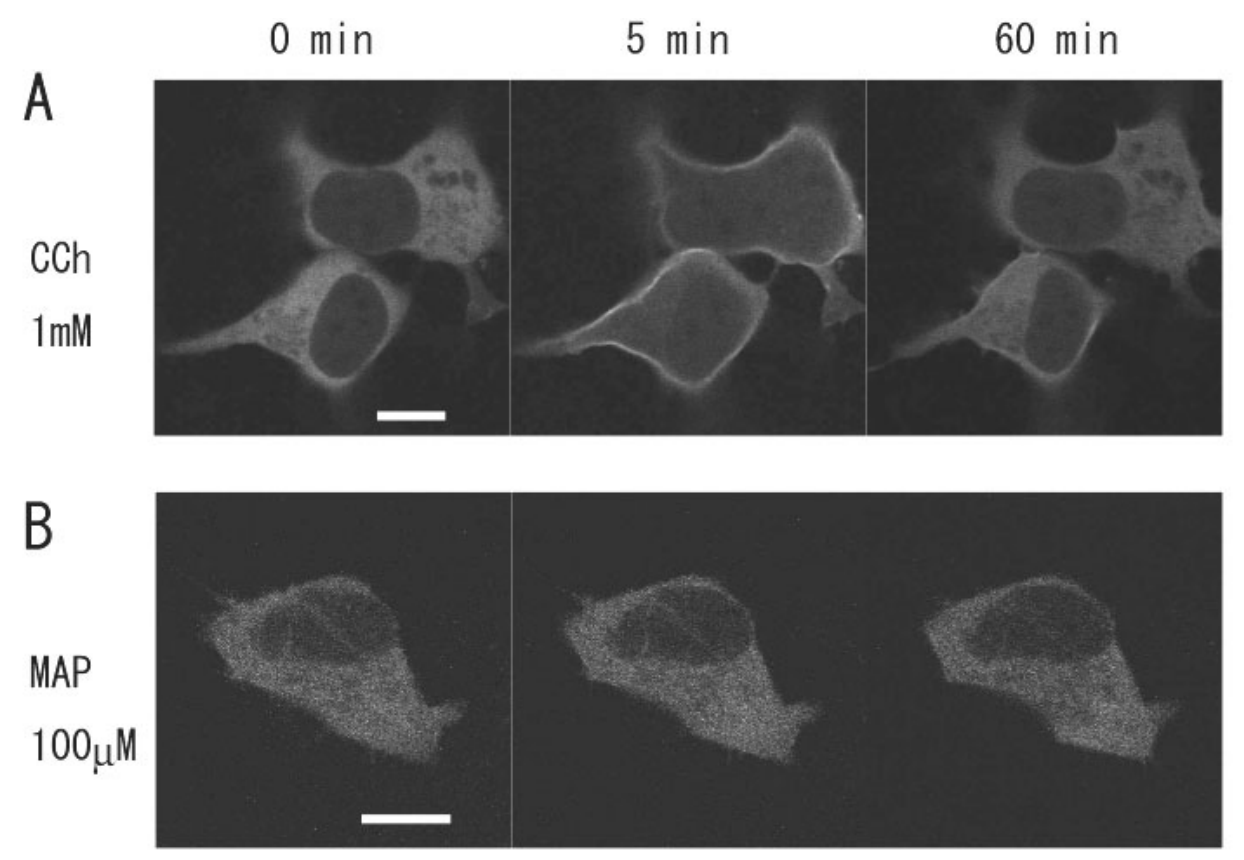

図 5 SHSY-5Y 細胞に GFP 融合 $\gamma$-PKC を発現させた後, カルバコールによる $\gamma$-PKC のトランスロケーション (A) を観察した. メタンフェタミンによる刺激では $\gamma$-PKC によるトランスロケーション (B) は観察できなかった. スケール $10 \mu \mathrm{M}$.

MAP は PKC を細胞膜へトランスロケーションて, D2 受容体の機能を変化させる可能性は少ないと考え られる。しかし，本デー夕はMAPの単回急性投与に おいての結果であり，MAPを長期暴露（慢性処置） した場合は，細胞膜へのトランスロケーションや PKC の活性化が起こる可能性も残しており，今後の 検討課題でもある.

\section{5. おわりに}

薬物依存形成についての電気生理学的手法およびラ イブイメージング法を用いた実験戦略と結果について 述べてきた。以上より，MAPを反復投与した場合， 腹側被蓋野ドパミンニューロンおよび側坐核ニューロ ンは感受性立進が起り，この現象はドパミン D 1 およ び D2 レセプターの感受性立進によることが見出され た.しかし，単一側坐核ニューロンのドパミン受容体 サブタイプ mRNAの発現パターンに変化はないこと から，この感受性の充進は細胞膜で作用するレセプタ 一密度の増加か, 細胞内伝達系の変化により D2 受容 体の機能が立進している可能性が考えられる。今後は この現象と PKC を含めた細胞内情報伝達系との関わ りについて検討していきたいと考えている.
謝辞：この総説を書くに当たり,この研究に従事していた だいた広島大学 大学院医歯薬学総合研究科 神経・精神薬 理学教室の皆様と同 薬効解析科学の井上 敦子先生にこの 場を借りまして感謝の意を表します。また, 薬理学サマー セミナー2004の「ストレス, 不安, 依存一行動実験のあり 方と戦略」に講師として発表の機会を与えて頂いた, 星薬 科大学の鈴木 勉先生と川崎医科大学の大熊 誠太郎先生に 深謝いたします。

$$
\text { 文献 }
$$

1) Spielmann $\mathrm{H}$, et al. Abstracts of the 23. ETS conference. 1995. p. 51.

1) Sato M, et al. Schizophr Bull. 1992;18(1):115-122.

2) Fujiwara Y, et al. Psychopharmacology. 1987;91(3):316-319.

3) Akiyama K, et al. Schizophr Res. 1994;12(3):251-257.

4) Ujike H, et al. Psychopharmacology (Berl). 1989;98(1):89-92.

5) Amano T, et al. Jpn J Pharmacol. 1994;65(3):293-295.

6) Amano T, et al. Ann N Y Acad Sci. 1996;80(1):136-147.

7) 天野託, 他. 日本アルコール・薬物医誌. 2002;37(1):31-40.

8) Hara M, et al. Neurosci Res. 1987;4(4):279-290.

9) Kamata K, et al. Life Sci. 1984;34(24):2419-2427.

10) Amano $T$, et al. Prog Neuropsychopharmacol Biol Psychiatry. 1995;19(1):105-116.

11) Amano T, et al. Neurosci Lett. 2003;347(2):89-92.

12) Grace AA, et al. Neuroscience. 1983;10(2):301-315.

13) Grace AA, et al. Neuroscience. 1983;10(2):333-348.

14) Grace AA, et al. Neuroscience. 1983;10(2):317-331.

15）酒井規雄, 他. 日薬理誌. 2003;121(6):421-434.

16) Kraft AS, et al. J Biol Chem. 1982;257(22):13193-13196. 
著者プロフィール

天野 託（あまの たく）

広島大学 大学院医歯薬学総合研究科 神経・精神薬理学教室 (旧医学部薬理学教室), 講師, 医学博士.

$\diamond 1990$ 年関西医科大学卒業, 同年 4 月- ’94 年 4 月京都大学医学部薬理学教室第 2 講座研究生, 同年 5 月- ’96 年 5 月広島大学医学部医 学科薬理学教室研究生, 同年 6 月より広島大学医学部医学科薬理学教室 助手, ’02 年 4 月より広島大学 大学院医歯薬学総合研究科 神経. 精神薬理学教室 助手, ’03 年 4 月より現職. ’96 年 10 月- ’98 年 9 月ミシガン大学 Mental Health Research Institute に留学.

○研究テーマ：中枢神経薬理, 薬物依存, セロトントランスポーターの機能解析. ○趣味：テニス, スキー, 映画鑑賞, スポーツ観戦.

関 貴弘（せきたかひろ）

広島大学 大学院医歯薬学総合研究科 神経・精神薬理学教室 (旧医学部薬理学教室), 助手, 薬学博士.

$\diamond 1996$ 年京都大学薬学部製薬化学科卒業, ’01 年同大学大学院薬学研究科博士課程, ’01 年 4 月より現職.

○研究テーマ：中枢神経系におけるリン酸化酵素の働きと疾患への関与. ○趣味：ゴルフ, スポーツ観戦, 競馬観戦.

松林 弘明（まつばやし ひろあき）

広島大学 大学院医歯薬学総合研究科 神経. 精神薬理学教室 (旧医学部薬理学教室), 助教授, 医学博士.

$\diamond 1983$ 年広島大学医学部医学科卒業, 同年広島大学 助手 医学部附属病院, '87 年竹原病院勤務, '89 年広島大学医学部薬理学講座 助 手, ’98 年同講師, ’03 年 4 月より現職, ’94-’96 年の間 米国メリーランド大学医学部薬理学教室留学.

○研究テーマ：神経・精神薬理学, 中枢型ニコチン受容体. 趣味：海洋魚類生息調査.

酒井 規雄（さかい のりお） 本誌 121 巻 6 号 434 頁（2003 年）をご参照ください.

笹 征史（ささ まさし）本誌 123 卷 6 号 $78 \mathrm{~A}$ （2004年）をご参照ください. 